\title{
Acute effects of crude oilfor three common mangrove seedling in segara anakan nature reserve (sanr) cilacap, Indonesia
}

\author{
Taufan Harisam ${ }^{\left.1,4^{*}\right)}$, Sugiyono ${ }^{2)}$, Rudhi Pribadi $^{3)}$, Asrul Sari Siregar ${ }^{1)}$, Sri Marnani ${ }^{1}$, Dewi Wisudyanti Budi \\ Hastuti ${ }^{1}$, Norman Arie Prayogo ${ }^{1,4)}$ \\ ${ }^{1}$ Fisheries and Marine Science Faculty, Jenderal Soedirman University, Indonesia \\ ${ }^{2}$ Biology Faculty, Jenderal Soedirman University, Indonesia \\ ${ }^{3}$ Fisheries and Marine Science Faculty, Diponegoro University, Indonesia \\ ${ }^{4}$ Centre for Maritime Bioscience Studies, Institute for Research and Community Service, Jenderal Soedirman University, \\ Indonesia
}

\begin{abstract}
The growth of three mangrove species seedlings,Bruguiera gymnorrhiza, Rhizophora apiculataand Ceriops decandra in sediments contaminated by crude oil. Thisresearchwas designed to evaluate the acute effects of crude oil on the growth and survival performance of mangrove seedling in 4-week field experiment. Three treatments(sub plot) were compared with the control (no oil added) usingi.e. $100 \mathrm{ml}, 120 \mathrm{ml}$ and $140 \mathrm{ml}$ crude oil applied once, in a split-plot design with nine replicates. The result showed the extent of survival has maximum for B. gymnorrhiza while it was minimum for $C$. decandra. The growth of mangrove seedlings was decrease with higher concentrations of crude oil. Stem height of B. gymnorrhiza seedling higher than $R$. apiculata and $C$. decandra.We observed, severe damage in the epidermis and the cortex at the root of all three types of mangrove seedlings when crude oil applied at $140 \mathrm{ml}$.
\end{abstract}

\section{Introduction}

The Segara Anakan Nature Reserve (SANR) is a mangrove fringed shallow coastal lagoon, and it is the largest still existing mangrovearea in Java, Indonesia [29]. The SANR is located along the southern coast of Java, Cilacap district, Indonesia, surrounded by an area of mangrove swamps, tributaries, and intertidal lands. Such an ecosystem serves a unique and a productive marine nursery and abundant aquatic ecosystem because the influence of the Indian Ocean may enter lagoon troughs in the western and eastern passages (Fig.1). Consisting of a mangrove fringed lagoon, SANR and its surrounding environment in the Cilacap coastal area are considered a unique ecological feature in Java, Indonesia. As an ecosystem, mangroves are important for overall ecological function as well as the economiesof populations living along the coast, where fisheries are a vital source of food and income [25].

Oil pollution poses a serious health risk to coastal ecosystems throughout the world. Many studies have investigated the effects of oil pollution on coastal marshes[15], [21] and mangroves [1], [7]. Crude oil is composed of up to 17,000 organic compounds, of which about $75 \%$ are hydrocarbons [11]. The light and medium compounds in oil remain at the surface and volatilize or degrade over time, while those with high molecular weight are deposited on sediments and retain toxic properties for years [22]. Despite their hydrophobic nature, polycyclic aromatic hydrocarbons (PAHs) can bio-concentrate and are toxic and mutagenic to organisms [7], [17].

Mangroves, which inhabit low wave energy, sheltered locations in intertidal zones of tropical and subtropical regions, are highly vulnerable to oil spills [17]. Oil can penetrate into soft sediments and coat aerial roots [11], [21], leading to oxygen deficiency, suffocation and growth irregularities in the shortterm and mortality in the long-term [31], [3]. Oil can persist in the mangrove environment under typical reduced conditions. Several studies have documented the effect of different types of crude oil on mangrove species under laboratory [27], [31] and field conditions [25][18].

Research on oil contamination have frequently concentrated on the mass mortality of plants after large-scale crude oil spills [11], [9]. Some studies focused on the effects of oil contamination on seedling establishment and growth under sub-lethal concentrations [21]. Responses of mangroves to oil treatment include reduction in foliage production and total plant biomass (Mille et al., 2006; Ke et al., 2011), reduction in the rate of 
photosynthesis and respiration [22], [18], increased mutation [3], development of anomalous growth forms [23], damage to root cell membranes [27], [13], impairment of transpiration [27], and increased mortality (Tam et al., 2005). In SANR area, oil pollution is one common pollution type that would cause a devastating impact on mangrove wetlands [24].SANR are vulnerable to contamination crude oil as an international marine are traversed carrier tankers and crude oil refineries from domestic crude oil industry.There is no available information by nowadays in SANR regarding to theeffects of crude oilexposure to mangrove system. Thus, our research aims to observe the possible effect of crude oil contaminationon survival rate, growth andanatomical structure of mangrove roots of Rhizophora apiculata,B. gymnorhiza and C. decandra.Sampling and preliminary treatment were carried out in September and October of 2017 in the SANR, Indonesia, and the analysis was conducted in the Fisheries and Marine Science Laboratory of Jenderal Soedirman University, Indonesia.

\section{Materials and methods}

\subsection{Description of study area}

The study conducted at Segara Anakan Nature Reserve (SANR) Cilacap, Central Java and lies within longitude $108^{\circ} 46^{\prime}-109^{\circ} 03^{\prime}$ and latitute $07^{\circ} 34^{\prime}-07^{\circ} 47^{\prime}$ (Figure 1). The climate of the area is basically that of equatorial tropical rainfall occurring almost through the year except the mouths of December, January and February, which are not completely free from rainfall in some years. The annual rainfall of the area is about $3,444 \mathrm{~mm}(11)$. Annual mean air temperature is $31.3{ }^{\circ} \mathrm{C}$ the highest monthly mean temperature was $29.7{ }^{\circ} \mathrm{C}$ (in August), and the lowest monthly mean temperature is $27.5^{\circ} \mathrm{C}$ (in January). The surface seawater temperature values range between $25.9{ }^{\circ} \mathrm{C}$ and $30.6{ }^{\circ} \mathrm{C}$, and the salinity of the seawater ranges between $8 \%$ and $20 \%$. The hydrology of the lagoon is governed by seasonally varying river runoff mainly of the Citanduy River in the west and tidal exchange with the Indian Ocean through two channels in the western (Plawangan) and eastern parts of the lagoon. The mixed and predominantly semidiurnal tide ranges between $0.4 \mathrm{~m}$ during neap tide and $1.9 \mathrm{~m}$ during spring tide [29].The Citanduy is the fifth largest river of Java in terms of discharge which is estimated to $227 \mathrm{~m}^{3}$ $\mathrm{s}^{-1}$ (dry season $171 \mathrm{~m}^{3} \mathrm{~s}^{-1}$, rainy season $283 \mathrm{~m}^{3} \mathrm{~s}^{-1}$; or $195 \mathrm{~m}^{3} \mathrm{~s}^{-1}$ on an annual average [29].

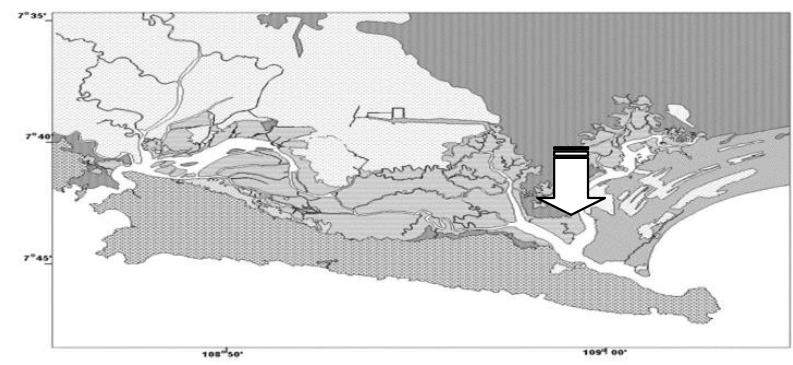

Fig 1. Location of sampling sites in the Segara Anakan Nature Reserve.

\subsection{Nursery preparation andSeedling establishment}

The sampling sites were established in a relatively undisturbedtidallyinundatedmangrovewetlandCilacap. Surface soil form the study area was collected $(0-20 \mathrm{~cm}$ depth) during tidal recession. The sediment surface samples $(5 \mathrm{~kg})$ were weighed and potted in polyethylene bags $(40 \times 60 \mathrm{~cm})$, leaving $10 \mathrm{~cm}$ at the upper end for irrigation of water. Each bag was labeled.

Propagules of B. Gymnorrhiza, R. apiculata, and $C$. decandrawere planted in $17 \mathrm{~cm}$ diameter $\times 15 \mathrm{~cm}$ height, $24 \mathrm{~cm} \times 21 \mathrm{~cm}$ and $11 \mathrm{~cm} \times 12 \mathrm{~cm}$ in plastic pots. All pots contained amixture of sand, potting soil and compost (1:2:1 volume based). Mangrove seedlings in good condition were carefully uprooted using hand trowel and transplanted into thepottedbags, ensuringthatthetherewasnorootdamage.Seedlings were grown for 2 months to eliminate effects of transplant shock. The seedlings were arranged in 9rowsofparalleltriplicatesat 1 mintervalsforeachtreatment $(0 \mathrm{ml}, 100 \mathrm{ml}, 120 \mathrm{ml}$ and $140 \mathrm{ml})$ Plate1. 
The stem height and leaf sizeof each mangrove seedlingswere monitored weekly for 4 weeks. The stem heights of $R$. apiculata, B. gymnorrhiza, and $C$. decandraseedlings were measured from the top of the seedlings where the stem emerged to the bottom of the mostdistal opened pairs of leaves, and the leaf area were measured individually using vernier calipers[4], [5].

\section{Root structure}

Anatomical damage resulting from oil pollution of the roots of three species were determined on plants of all Treatments on 4 week. Typical transections of live mediate and fine roots were observed with an Microscope (Boeco, Germany).

\subsection{Treatments}

Treatment was by applying the crude oil that commenced at the end of 60 day acclimation period. The crude oil constitutes of n-alkane-containing oil such as saturates $(56 \%)$, aromatics $(31 \%)$, polars $(11 \%)$, and asphaltenes (2\%), it also has $35.3^{\circ}$ API gravity and contains $0.1 \%$ sulphur content. The accute treatment, consisted of a one-time application of $120 \mathrm{~mL}$ crude oil add on the surface of the mud [4], [5]. Stem height at the first internode and leaf area were monitored weekly for 4 weeks. Any yellowing of leaves and seedling survivalwere recorded.

\subsection{Data analyses}

Mean and standard deviation (S.D.) values of triplicates were calculated. Before subject to parametric statistical analyses, the data were tested for the assumptions of normality of distribution and homogeneity of variance. All tested data satisfied the assumptions and no data transformation was necessary. A parametric two-way analysis of variance (ANOVA) with repeated measures was used to compare the effects of oil dose and exposure time on plant growth, including the increment of stem height and change of leaf area. The effects of crude oil dose on mangrove plants were evaluated by one-way multivariate analysis of variance (MANOVA). If the statistical results are significant at $\mathrm{p} \leq 0.05$, Tukey'smultiple comparisons as post-hoc tests were applied to locate the differences. All statistical analyses were performed using the software, Statistical Package for Social Sciences (SPSS) 11.0 for Windows, SPSS Inc. IL, USA

\section{Results}

\subsection{Seedling Survival}

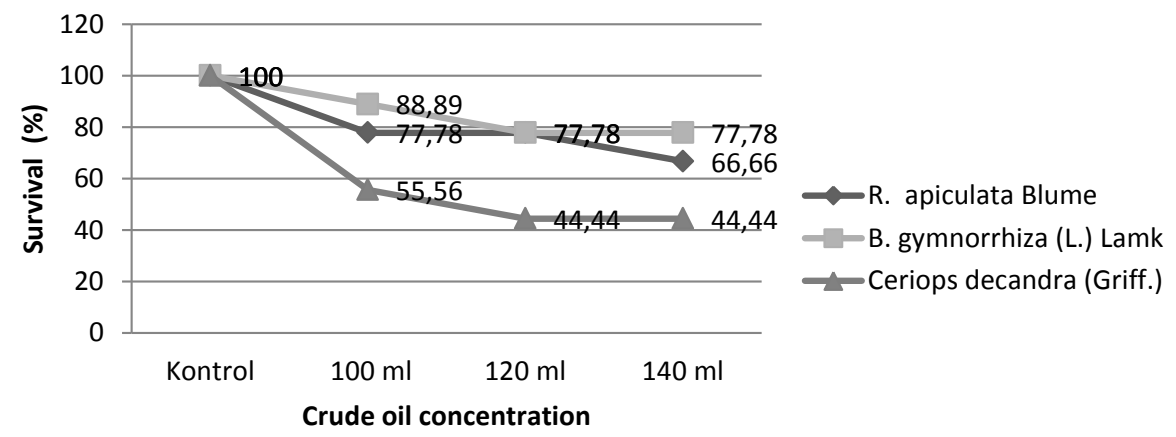

Fig. 2. Effects of oiling on seedling survival

Among the three mangrove species, B. gymnorrhiza was the most tolerantspeciestospentlubricatingcrude $\quad$ oil,with $100 \%, \quad 88.89 \%, \quad 77.78 \% \quad$ and $\quad 77.78 \%$ survival oftheseedlingsinthetreatmentswith $0 \mathrm{ml}, 100 \mathrm{ml}, 120 \mathrm{ml}$ and $120 \mathrm{ml}$, respectively R. apiculata ranked No. 2 in 
oil tolerability, with $66.66 \%$ seedlings survived at $140 \mathrm{ml}$ oil. C. decandra the most vulnerable species to oil contaminationwith $100 \%, 55.56 \%, 44.44 \%$ and $44.44 \%$ survival of the seedling for all treatment. Most of the resident ground dwelling macrofauna were killed by oil.

\subsection{Growth response}

\subsubsection{Stem growth}

Stem growth of three seedling mangrove was reduced by acute effect of crude oil (Fig. 3). For the always in field group, control plants displayed relatively linear growth over the study period. Growth rates of one-time oil treatments were less than that of the control.

The growth of all mangrove species, even exposed to the lowest oil dose (100 ml), was reduced compared to that in the control.Crude oil dose effects on stem growth (expressed as stem height increment) of the three mangrove species were significant $(F=0.657, \mathrm{p}=0.005)$. $R$. apiculata, in which significant reduction in the degree of stem height increment was observed $(F=4.344, \mathrm{p}=0.005)$.

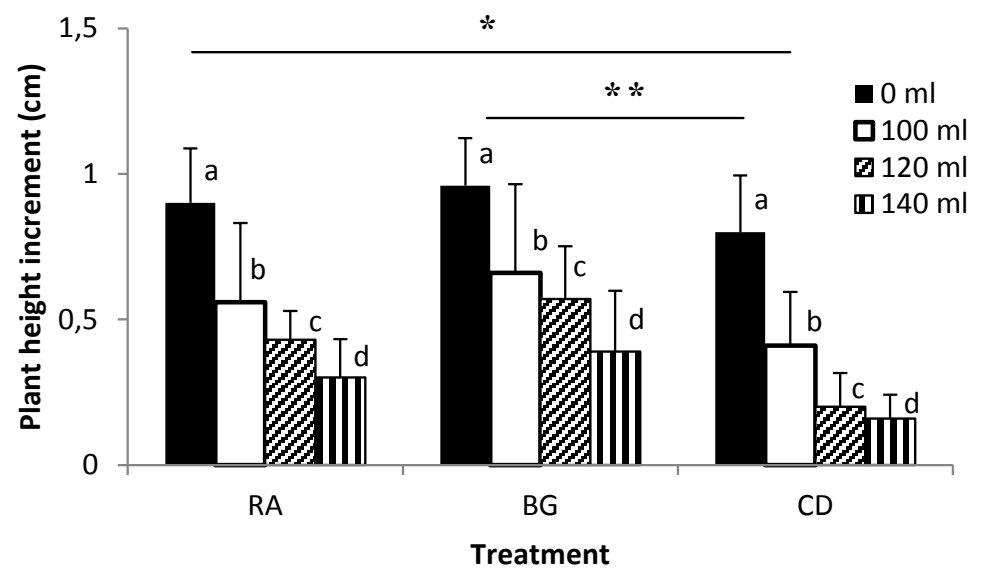

Fig. 3.Effects of oiling on seedling height increment (final seedling height - initial) $\left(*\right.$ : $\mathrm{P}<0.05,{ }^{* *}$ : 0.001$)$. RA: Rhizophora apiculata, BG: Bruguiera gymnorrhiza, CD: Ceriops decandra.

\subsubsection{The leaf size}

Leaf size of three seedlings mangrove followed a pattern similar to that describe for stem growth (Fig. 4). For all weeks of the study, there was a significant effect of oil treatment, with tipically more leaves size by control plants. The leaf size of $R$. apiculata, B. Gymnorrhiza and C. Decandradecreased significantly with increasing oil doses.Acute exposure of the mangrove seedlings to the crude oil had significant effect on leaf size. 


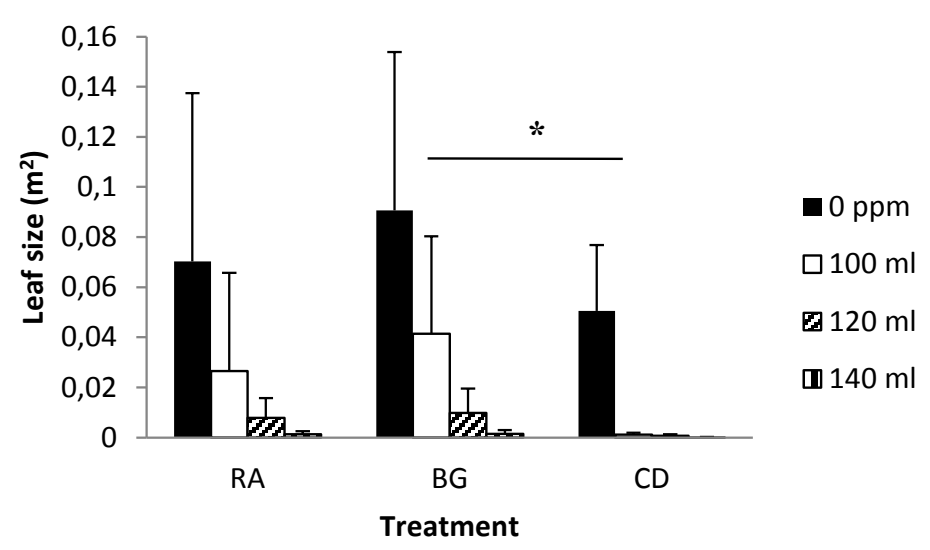

Fig. 4.Effects of oiling on plant leaf size $(*: \mathrm{P}<0.05)$. Bars with differentletters are significantly different at $\mathrm{P} \leq$ 0.05 using Tukey-Kramer multiple comparisonstest.

\subsubsection{Root structure}

Damage by base-oiling was found to the roots of B.gymnorrhiza, $R$. apiculataand $C$. decandra (Fig.5). The worst damage occurred at a concentration of $140 \mathrm{ml}$, damage occurred in the epidermis and the cortex on the three types of mangrove seedling roots. The roots of oiledseedlings were black in colour in contrast to the brownish andwhitish root systems in unoiled seedlings of B.gymnorrhiza, $R$. apiculataand $C$. decandra, respectively, and a strong oily smell wasnoted. From microscope observation oftypical root transections, oiling crude oil resulted in damageto conducting tissues (epidermis and cortex) in fine roots but not in mediate roots. 

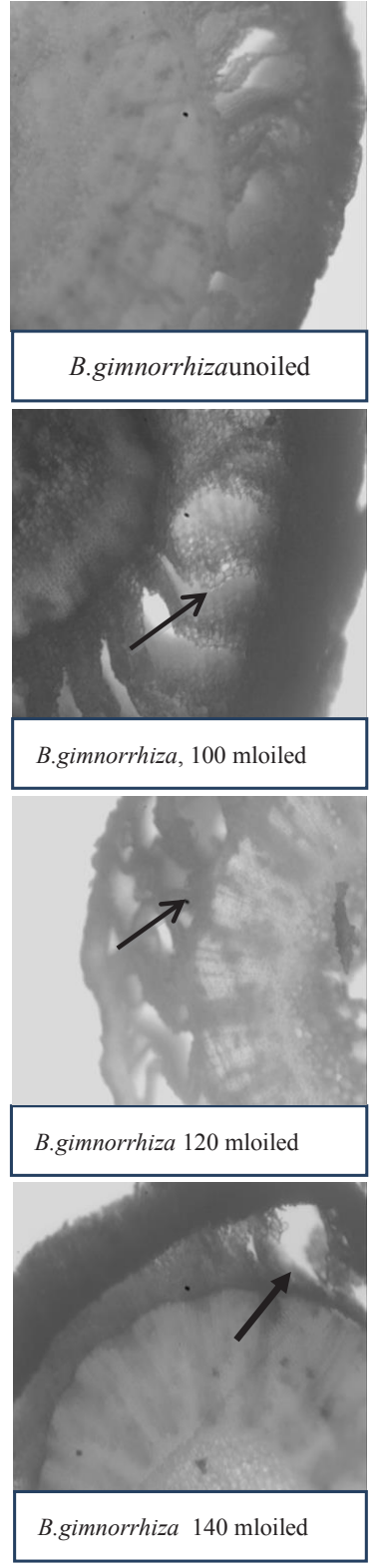
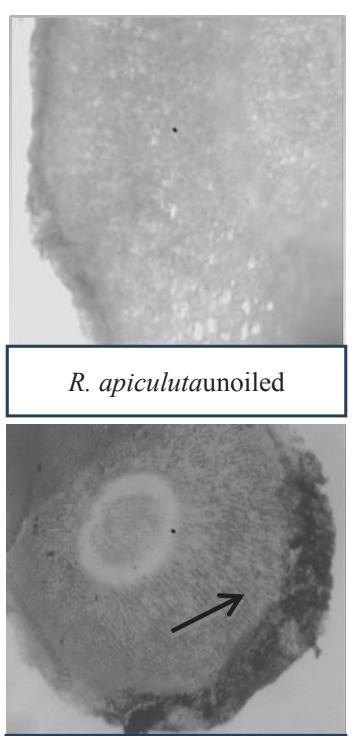

R. apiculuta 100 mloiled

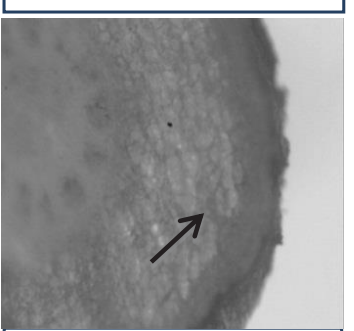

R. apiculuta 120 mloiled

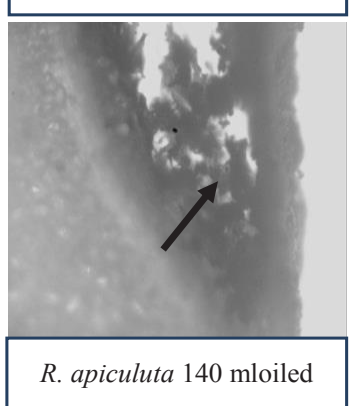

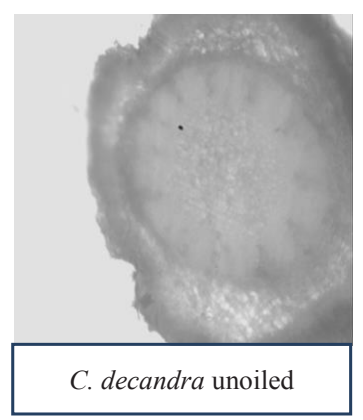

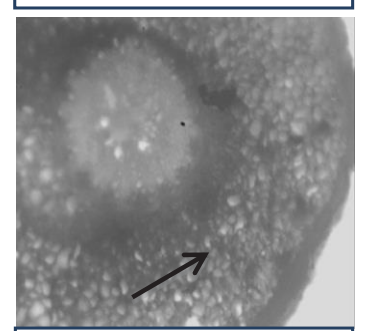

C. decandra 100 mloiled
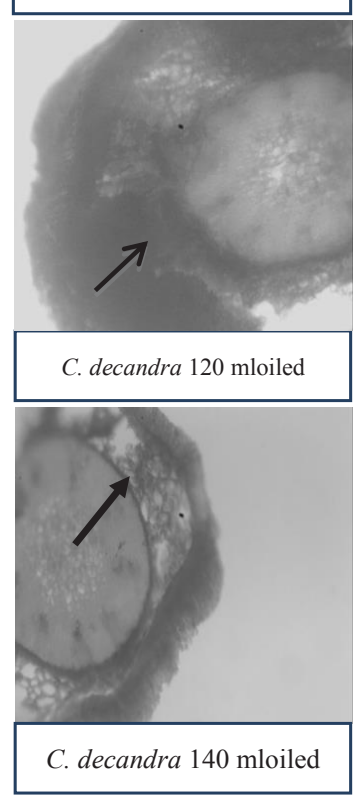

Fig. 5. Effects of oiling seedling on typical transections of fine roots (Scale: 1:40).

\section{Discussion}

Oil dose is one of the most important variables that determine the degree of damage to seedlings mangroves. A one-time addition of $120 \mathrm{~mL}$ oil, an acute oiling with sediment saturation, reduced the survival and growth of red mangrove seedlings more significantly than those received weekly chronic oiling (weekly addition of $15 \mathrm{~mL}$ oil for 8 weeks) even though the accumulative amount of oil given to plants in the weekly treatment was equivalent to the quantity given in the one-time treatment [21].

This research has clearly demonstrated that seedling mangroves are extremely sensitive andvulnerabletooilcontamination, as reported alsoinseveralothersstudies[7], [11], [25]. Oileffectsonseedling mangrovesare complex becauseofthelong-livednatureofthetreesandtheir tendency toexhibitshorttermeffects, aswellassub-lethal responses, whichmaypersistfordecades.Shorttermadverse effects 
suchassenescence, leafwilting,anddefoliation,reported in previousstudies[7], [4], were also observedinoilcontaminatedtrees of R. apiculataB. gymnorrhizaand C. decandrain thisresearch.

Our field research on the effects of crude oil exposed to different treatments (acute) indicated considerable variation in seedling reaction ranging from survival, growth response and root histology. In this field research we have shown that a form of crude oil, can adversely affect seedlings mangrovesurvival, growth, and root histology. It is clear from our experiment that $C$. Decandra are more sensitive to lubricating oil than are seedlings of B.gymnorrhizaandR.apiculata. This research has demonstrated that trees and seedlings of $B$. gymnorrhiza, but not of $R$. Apiculata and C. Decandra, have the ability to initiateadventitious roots following oiling of stem sand the root system.In A. marina and Aegiceras corniculatum, lubricatingcrude oilwasshowntodamage the xylemvesselsoffineroot [4]. The primary effect of toxic hydrocarbons works probably via disruption of membranes in the conducting tissue [12], [30].

Oiling crude oil resulted in damageto conducting tissues (epidermis and cortex) in fine roots but not in mediate roots. The greatest damageat a concentration of $140 \mathrm{ml}$. Destruction of conducting tissues in fine roots will undoubtedly have resulted in the reduction of transpiration, a frequently reported effect of oils on mangroves [11], 27].

In addition to physiological and morphological effects on mangrove seedling, oil also alters the chemical and physical characteristics of the sediments [10], including decreases in dissolved oxygen concentrations, $\mathrm{pH}$, salinity, redox and potentials of the interstitial water [23]. The highly reducing soil redox potentials increase oxygen stress in roots [6], [19], reduce root respiration, water relations and disrupt ion and subsequently growth [12].

\section{Conclusions}

B. gymnorrhiza was the mosttolerantspeciesto crude oil in accute effect softthereductionin andmortality,followedby $R$. Apiculata were themostvulnerablespeciestooiltoxicity and C. Decandra are more sensitive to lubricating crude oil in accute effect.

The work described in this paper was supported by research grants from BLU Jenderal Soedirman University, Indonesia.

\section{References}

1. Andersen, L.E., Melville, F., Jolley, D., 2008. An assessment of an oil spill in Gladstone, Australia impacts on intertidal areas at one month post-spill. Mar. Pollut. Bull. 57, 607-615.

2. Bjorlykke, K., 2011. Petroleum Geoscience: From Sedimentary Environments to Rock Physics. Springer, New York (517 pp.).Bruguiera gymnorrhiza to oil contamination. Flora 205, 357-362.

3. Cavalcante, R. M., Sousa, F. W., Nascimento, R. F., Silveira, E. R., Freire, G. S. S., 2009. The impact of urbanization on tropical mangroves (Fortaleza, Brazil): evidence from PAH distribution in sediments. J. Environ. Manag. 91, 328-335.

4. Chindah. A.C.. S.A. Braide. J. Amakiri and J. Onokurhefe. 2007. Effect of Crude Oil on The Development of Mangrove (Rhizophora mangle L.) Seedling from Niger Delta. Nigeria.J. Revista UDO Agricola.7. 181-194.

5. Chindah. A.C.. S.A. Braide. J. Amakiri and J. Onokurhefe. 2008.

6. Dicks, B.,1986.Oil and the black mangrove Avicennia marina in the Northern Red Sea. Mar. Pollut.Bull.7,500-503.

7. Duke, N. C., Ellison, J., Burns, K. A., 1998. Surveys of Oil Spill Incidents Affecting Mangrove Habitat in Australia: A Preliminary Assessment of Incidents, Impacts on Mangroves, and Recovery of Deforested Areas. Australian Petroleum Production and Exploration Association (APPEA), Canberra, 646-654.

8. Duke, N.C., Pinzon, Z.S., Prada, M.C., 1998. Large-scale damage to mangrove forests following two large oil spills in Panama. Biotropica 29, 2-14. 
9. Duke, N.C., Ramsay, M.A., Swannell, R.P.J., Shipton, W.A., Hill, R.T., 2000. Effect of bioremediation on the microbial community in oiled mangrove sedimentsMar. Pollut. Bull. 41, 413419.

10. Farias, C.O., Hamacher, C., Wagener, A.D.L.R., Scofield, A.D.L., 2008. Origin and degradation of hydrocarbons in mangrove sediments (Rio de Janeiro, Brazil) contaminated by an oil spill. Org. Geochem. 39, 289-307.

11. Getter, C. D., Ballou, T. G., Koons, C. B., 1985. Effects of dispersed oil on mangroves: synthesis of a seven year study. Mar. Pollut. Bull. 16, 318-324.

12. Gilfillan, E.S., Page, D.S., Bass, A.E., Foster, J.C., Fickett, P.M., Ellis, W.G., Rusk, S., Brown, A.C., 1989. The use of $\mathrm{Na}-\mathrm{K}$ ratios in leaf tissues to determine effects of petroleum on salt exclusion in marine halophytes. Mar. Pollut. Bull. 20, 272-276.

13. Kang, F., Chen, D., Gao, Y., Zhang, Y., 2010. Distribution of polycyclic aromatic hydrocarbons in subcellular root tissues of ryegrass (Lolium multiflorum Lam.). Plant Biol. 10, 210.

14. Ke, L., Zhang, C., Wong, Y. S., Tam, N. F. Y., 2011. Dose and accumulative effects of spent

15. Lin, Q., Mendelssohn, I.A., Suidan, M.T., Lee, K.,Venosa, A.D. 2002. The dose response relationship between No.2 fuel oil and the growth of the saltmarsh grass, Spartina alterniflora. Mar. Pollut. Bull. $44,897-902$.

16. Meudec, A., Dussauze, J., Deslandes, E., Poupart, N., 2006. 44,8-92.

17. Mille, G., Guiliano, M., Asia, L.,Malleret, L., Jalaluddin, N., 2006. Sources of hydrocarbons in sediments of the Bay of Fort de France (Martinique). Chemosphere 64, 1062-1073.

18. Naidoo, G., Naidoo, Y., Achar, P., 2010. Responses of the mangroves Avicennia marina andPAHs into internal shoot tissues of a halophytic plant artificially exposed to petroleum polluted-sediments. Chemosphere 65, 474-81.

19. Pezeshki, S.R., DeLaune, R.D., Jugsujinda, A., 2001. The effects of crude oil and the effectiveness of cleaner application following oiling on US Gulf of Mexico coastal marsh plants. Environ. Pollut. 112, $483-489$.

20. Pezeshki, S.R., Hester, M.W., Lin, Q., Nyman, J.A., 2000. The effects of oil spill and clean up on dominant US Gulf coast marsh macrophytes: a review. Environ. Pollut. 8, 129-139.

21. Proffitt, C. E., Devlin, D. J., Lindsey, M., 1995. Effects of oil on mangrove seedlings grown under different environmental conditions. Mar. Pollut. Bull. 30, 788-793.

22. Reed, M., Johansen, O., Brandvik, P.J., Daling, P., Lewis, A., Fiocco, R., Mackay, D., Prentiki, R., 1999. Oil spill modeling towards the close of the 20th century: overview of the State of the Art. Spill Sci. Technol. Bull. 5, 3-16.

23. Suprayogi, B., Murray, F., 1999. A field experiment of the physical and chemical effects of two oils on mangroves. Environ. Exp. Bot. 42, 221-229.

24. Syakti, AD., Nuning V.H., Endang H., Anne P., Pierre D., 2013. Source apportionment of sedimentary hydrocarbons in the Segara Anakan Nature Reserve, Indonesia. Marine Pollution Bulletin 74 (2013) $141-148$.

25. Tam, N. F. Y.,Wong, T. W. Y.,Wong, Y. S., 2005. A case study on fuel oil contamination in a mangrove swamp in Hong Kong. Mar. Pollut. Bull. 51, 1092-1100.

26. Watts, A. W., Ballestero, T. P., Gardner, K. H., 2006. Uptake of polycyclic aromatic hydrocarbons (PAHs) in saltmarsh plants Spartina alterniflora grown in contaminated sediments. Chemosphere 62, $1253-1260$. 
27. Youssef T, Ghanem A, 2002. Salt secretion and stomatal behaviour in Avicennia marina seedlings fumigated with the volatile fraction of light Arabian crude oil[J]. Environ Poll, 116: 215-223.

28. Youssef, T., and Ghanem, A., 2002b. Physiological responses and accumulation of polynuclear aromatic hydrocarbons in Avicennia marina seedlings treated with the water soluble fraction of light Arabian crude oil. Environmentalist 22, 149-159.

29. Yuwono, E; TC. Jennerjahn; I. Nordhaus; E.A. Riyanto; M.H. Sastranegara and R. Pribadi. Asian Journal of Water Environment Pollution. 4, no. 1, pp: 61-70 (2007)

30. Zhang, C. G., Leung, K. K.,Wong, Y. S., Tam, N. F. Y., 2007. Germination, growth and physiological responses of mangrove plant (Bruguiera gymnorrhiza) to lubricating oil pollution. Environ. Exp. Bot. $60,127-136$. 